Springer Link

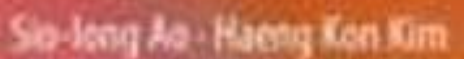

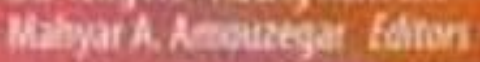

Transactions on Engineering Technologies

World congess on teyinering and Computer sinnce 2017

Transactions on Engineering Technologies

The World Congress on Engineering and Computer Science

WCECS 2017: Transactions on Engineering Technologies pp 143-156| Cite as

\title{
Addressing the Challenges of Igbo Computational Morphological Studies Using Frequent Pattern-Based Induction
}

- Authors

- Authors and affiliations

- Olamma U. Iheanetu

- Obododimma Oha

Conference paper

First Online: 25 October 2018

Abstract 
Computational studies of Igbo language are constrained by non-availability of large electronic corpora of Igbo text, a prerequisite for data-driven morphological induction. Existing unsupervised models, which are frequent-segment based, do not sufficiently address non-concatenative morphology and cascaded affixation prevalent in Igbo morphology, as well achieving affix labelling. This study devised a data-driven model that could induce non-concatenative aspects of Igbo morphology, cascaded affixation and affix labelling using frequent pattern-based induction. Ten-fold Cross Validation (TCV) test was used to validate the propositions using percentages. An average accuracy measure of $88 \%$ was returned for the developed model. Ten purposively selected Igbo first speakers also evaluated samples of 100 model-analysed words each and the mean accuracy score of $82 \%$ was recorded. We conclude that morphology induction can be realized with a modestly sized corpus, demonstrating that electronic corpora scarcity does not constrain computational morphology studies as it would other higher levels of linguistic analysis.

\section{Keywords}

Computational morphology Frequent pattern-based morphology Igbo computational morphology Igbo morphology Rule-based learning Morphology induction

This is a preview of subscription content, log in to check access.

\section{Notes}

\section{Acknowledgements}

I acknowledge the entire management and staff of Covenant University, Ota, Nigeria for financing the publication of this material.

The tests and results presented here are those contained in an unpublished thesis of Iheanetu (2015). I acknowledge all my supervisors for their immense contributions to this study.

The Catholic Arch Bishop of Owerri, His Grace, Dr. Amarachi Obinna is highly appreciated for the release and permission to use electronic prints of Odenigbo lecture series. Finally, I acknowledge the management and staff of Africana-Fep publishers for the permission to use Baibụl Nsọ Nhazi Katọlik for the purposes of this study.

\section{References}

1. 1 .

O. Awobuliyi, Eko Iseda-Oro Yoruba (Montem Paper Backs, Akure, Ondo state, 2008)Google Scholar

2. 2 . 
K.R. Beesley, L. Karttunen, Finite State Morphology (CSLI Publications, Stanford, United States of America, 2003)Google Scholar

3. 3.

R. Blench, Atlas of Nigerian languages, 3rd edn. (2012) Retrieved from 9 J une 2015, www.rogerblench.info/ Language/ Africa/ Nigeria/Atlas\%20of\%20Nigerian\%20La nguages-\%20ed\%20III.pdf

4. 4 .

M. Creutz, Induction of the morphology of natural language: unsupervised morpheme segmentation with application to automatic speech recognition. Ph.D. Thesis, Computer and Information Science Department, Helsinki, University of Technology, Espoo (2007), xi+110 pp.Google Scholar

5. 5 .

G. De Pauw, G. De Schryver, Improving the computational morphological analysis of a Swahili corpus for lexicographic purposes. Lexikos Afr. Assoc. Lexicogr. (AFRILEX)reeks Series 18, 303- 318 (2008) Google Scholar

6. 6.

N. Emenanjo, The interfix: an aspect of universal morphology. J . West Afr. Lang.

XII 1(1982), 77- 88 (1982) Google Scholar

7. 7.

N. Emenanjo, Elements of Modern Igbo Grammar (University Press Limited (UPL), Ibadan, 1987) Google Scholar

8. 8.

M.A. Fullwood, T.J . O'Donnell, Learning non-concatenative morphology, in Proceedings of the Workshop on Cognitive Modeling and Computational Linguistics, 8 August 2013, Sofia, Bulgaria, pp. 21-27Google Scholar

9. 9.

Gale Group Inc., Igbo. J unior Worldmark Encyclopedia of World Cultures (1999). Retrieved from 10 August 2010, Encyclopedia.com: http:// www.encyclopedia.com/doc/ 1G2-3435900354.html

10.10.

J . Goldsmith, Unsupervised learning of the morphology of a natural language. Mass. Inst. Technol. (MIT) Press J . 27(2), 153- 198 
(2001). https:// doi.org/ 10.1162/089120101750300490MathSciNetCrossRefGoogle Scholar

11.11

J. Goldsmith, An algorithm for the unsupervised learning of morphology. Nat. Lang. Eng. 1(1) (2005). Cambridge University Press. Retrieved from, http:// hum.uchicago.edu/ jagoldsm/ Papers/algorithm.pdf

12. 12

H. Hammarström, Unsupervised learning of morphology and the languages of the world, Doctoral thesis, Department of Computer Science and Engineering, Chalmers University of Technology and University of Gothenburg, Sweden (2009), 284 pp.Google Scholar

H. Hammarström, L. Borin, Unsupervised learning of morphology. MIT Press J . 37(2), 309- 350 (2010) Google Scholar

14. 14

Z. Harris, Morpheme Boundaries within Words: Report on a Computer Test. Transformations and Discourse Analysis Papers (1967), p. 73Google Scholar

15.15

O.U. Iheanetu, Data-driven model of Igbo morphology. Doctoral thesis, Africa Regional Centre for Information Science, (ARCIS), University of Ibadan, Nigeria (2015) 284 pp. Google Scholar

16. 16

O.U. Iheanetu, O. Oha, Some salient issues in the unsupervised learning of Igbo morphology, in World Congress on Engineering and Computer Science 2017. Lecture Notes in Engineering and Computer Science, 25- 27 October 2017, San Francisco, USA, pp. 389- 393Google Scholar

17.17.

P. Lambert, M. Costa-jussa, R.E. Banchas, Introduction, in Workshop on Creating Cross-Language Resources for Disconnected Languages and Styles, 27th May 2012. Istanbul, Turkey (2012)Google Scholar

18. 18.

J .J . McCarthy, A prosodic theory of nonconcatenative morphology. Linguist. Inq. 12(3), 373- 418 (1981) Google Scholar 
19.19.

P. MacClanahan, G. Busby, R. Haertel, K. Heal, D. Lonsdale, K. Seppi, E. Ringer, A probabilistic morphological analyser for Syriac, in Proceedings of the Conference on Empirical Methods in Natural Language Processing (2010), pp. 810-820 $\underline{\text { Scholar }}$

20.20.

B.M. Mba, A Minimalist Theory and Application to Igbo (Catholic Institute for Development J ustice and Peace (CIDJ AP) Press, Enugu, 2011)Google Scholar

21.21.

B.M. Mba, Circumfixation: interface of morphology and syntax in Igbo derivational morphology. IOSR J. Humanit. Soc. Sci. (J HSS) 5(6), 1- 8 (2012) CrossRefGoogle $\underline{\text { Scholar }}$

22. 22.

O.M. Ndimele, A First Course on Morphology and Syntax (Emhai Printing and Publishing Company, Port Harcourt, 1999)Google Scholar

B.I.N. Osuagwu, G.I. Nwaozuzu, G.A. Dike, V.N. Nwaogu, L.C. Okoro, Fundamentals of linguistics (Colon Concept Ltd, Owerri, 1997)Google Scholar

24. 24 .

L.M. Paul, G.F. Simons, C.D. Fennig (eds.), Ethnologue: Languages of the World, Eighteenth Edition (SIL International, Dallas, Texas, 2015). Retrieved from $20 \mathrm{~J}$ une 2015, http:// www.ethnologue.com/language/ibo

A.K. Simpson, The origin and development of nonconcatenative morphology. Ph.D. Thesis. Graduate Division of the Department of California (2009), 194 pp.Google $\underline{\text { Scholar }}$

26. 26.

University of California, Los Angeles (UCLA) Language Materials Project 2009. Igbo. UCLA Language Materials Project. Retrieved from 20 October 2010, http:// www.lmp.ucla.edu/ Profile.aspx?LangID=13\&menu=004 
V.N. Vapnik, An overview of statistical learning theory. IEEE Trans. Neural Netw. 10(5), 988- 999 (1999)CrossRefGoogle Scholar

\section{Copyright information}

(C) Springer Nature Singapore Pte Ltd. 2019

\section{About this paper}

CrossMark

Cite this paper as:

Iheanetu O.U., Oha O. (2019) Addressing the Challenges of Igbo

Computational Morphological Studies Using Frequent Pattern-Based

Induction. In: Ao SI., Kim H., Amouzegar M. (eds) Transactions on

Engineering Technologies. WCECS 2017. Springer, Singapore

- First Online25 October 2018

- DOIhttps://doi.org/10.1007/978-981-13-2191-7_11

- Publisher NameSpringer, Singapore

- Print ISBN978-981-13-2190-0

- Online ISBN978-981-13-2191-7

Buy eBook

EUR 160.49

Buy paper (PDF)

Springer Nature

(C) 2019 Springer Nature Switzerland AG. Part of Springer Nature.

Not logged in Not affiliated 165.73.192.254 